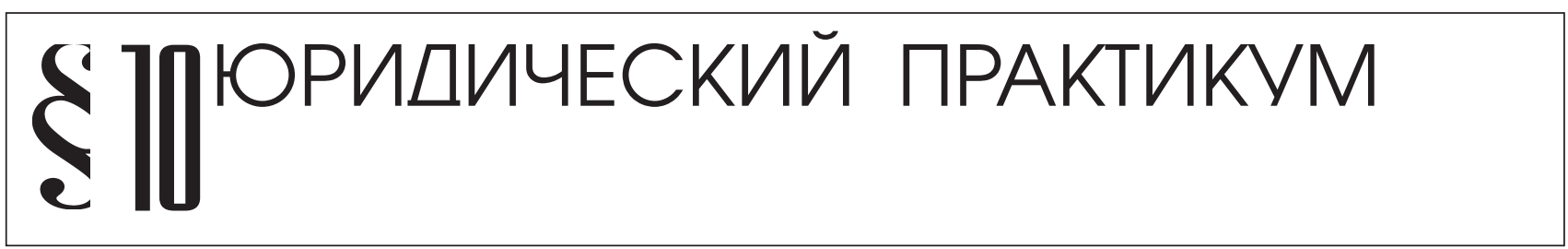

Ю.И. Павлова

\title{
ОСОБЕННОСТИ КОЛЛИЗИОННОГО РЕГУЛИРОВАНИЯ ТРУБОПРОВОДНОЙ ТРАНСПОРТИРОВКИ
}

\begin{abstract}
Аннотация: В данной статье автором рассмотрены возможные коллизионные нормы, применимые к трубопроводной транспортировки. Особое внимание уделено трубопроводному транспорту как объекту имущественного комплекса, выделены особенности субъектного состава, а также рассмотрены варианты возможного коллизионного регулирования отнотений по трубопроводной транспортировке.

Каждый вид транспортировки имеет свои особенности регулирования в международном частном праве. Как верно отмечено М.В. Филимоновой, один вид транспорта регулируется только унифицированными материальными нормами (воздушный транспорт), для другого оптимальна унификаиия коллизионных норм, позволяюших сохранять связь с «материнской», национально правовой системой (железнодорожный и автомобильный транспорт); в одних случаях более подходит универсальная (воздушный транспорт) унификаиия, а в других - региональная (трубопроводный, железнодорожный транспорт) унификаиия.
\end{abstract}

Ключевые слова: Юриспруденция, коллизия, норма, имущество, комплекс, трубопровод, транспортировка, транснациональная, компания, регулирование

аждый вид транспортировки имеет свои особенности регулирования в международном частном праве ${ }^{1}$. Как верно отмечено М.В. Филимоновой, один вид транспорта регулируется только унифицированными материальными нормами (воздушный транспорт), для другого оптимальна унификация коллизионных норм, позволяющих сохранять связь с «материнской», национально правовой системой (железнодорожный и автомобильный транспорт); в одних случаях более подходит универсальная (воздушный транспорт) унификация, а в других - региональная (трубопроводный, железнодорожный транспорт) унификация ${ }^{2}$.

В мире не существует особого, обособленного от национальных транспортных систем международного транспорта, предназначенного исключительно для международных перевозок грузов и пассажиров. Международные перевозки обслуживаются национальными перевозчиками различных государств. Осуществляя международные транспортные операции, перевозчики оказывают грузовладельцам транспортные услуги, которые являются специфическим товаром международной торговли.

${ }^{1}$ Кокин А.С., Международная морская перевозка груза. М.: Волтерс Клувер, 2007. С.194

${ }^{2}$ Филимонова М.В. К вопросу о регулировании трансграничной трубопроводной транспортировки. Право: теория и практика. № 13 2006. С. 5
Государства, заинтересованные в расширении деятельности своих национальных транспортных предприятий в международных сообщениях, всегда стремились к международному сотрудничеству в целях выработки унифицированных условий перевозок грузов и пассажиров, а также согласования юридических норм, относящихся к режиму нахождения перевозочных средств и обслуживающего их персонала в пределах юрисдикции договаривающихся сторон и по многим другим вопросам. В результате этих усилий на межгосударственном уровне заключено значительное число международных соглашений по отдельным видам транспорта.

Особенностью международного транспортного права является, то, что на уровень универсально международно-правового регулирования вышли только отношения, которые возникли в сфере морского, воздушного и автомобильного транспорта. Ввиду того, что отношения в этих сферах зародились достаточно давно. Что касается других видов современного транспорта, например, трубопроводного, железнодорожного, речного, то здесь, как правило, имеет значение действие региональных международно-правовых актов.

Несмотря на то, что в настоящее время основные моменты международных перевозок урегулированы международными унифицированными договорами. Метод унификации не может быть единственно возможным и оправданным. Даже самая полная унификация материаль- 


\section{Право и политика $3(159) \cdot 2013$}

ных норм международных перевозок посредством международных конвенций не гарантирует отсутствие оснований для возникновения коллизий по вопросам, не решенным в договорах. Даже при наличии договора, создающего единообразные в определенной области правоотношений нормы, в государствах — участниках данного договора имеют место различия в толковании отдельных его понятий. Кроме того, следует учитывать и тот факт, что ни один из действующих в настоящее время международных договоров не является универсальным и по той причине, что не охватывает всех или абсолютного большинства государств, участвующих в международных транспортных отношениях, а также они не могут охватить весь круг вопросов. С другой стороны, возникают новые отношения, которые не являются предметом регулирования уже существующих договоров, которые не достаточно урегулированы внутренним законодательством.

Общепризнанно, что при отсутствии унифицированных материально-правовых норм следует руководствоваться нормами национального права в соответствии с коллизионными нормами транспортных конвенций, национального законодательства, а также на основе коллизионных норм Римской конвенции о праве, применимом к договорным обязательствам ${ }^{3}$.

Рассматривая коллизионное регулирование трубопроводной транспортировки, в первую очередь, хотелось бы отметить, что деятельность в области трубопроводного транспорта многогранна, это и отношения по строительству трубопроводов, эксплуатации, утилизации, концессионные отношения, а также деликтные, и выбор применимого права зависит от этапа, на котором ведется такая деятельность. Достаточно сложный субъектный состав играет немало важную роль в выборе применимого права.

В области международных перевозок, применяются как специальные «транспортные» формулы прикрепления, которые характерны только для международных транспортных отношений, например, право страны отправителя или получателя, lex banderae, так и классические коллизионные принципы, как закон места заключения договора, закон суда, закон государства, где имеет основное место деятельности (место жительства, место регистрации) перевозчик. Коллизионные нормы, используемые при регулировании перевозок, схожи с коллизионными нормами, устанавливаемыми для других видов международных экономических связей ${ }^{4}$. Так, коллизионная привязка lex rei sitae в случае поиска применимого права для определения законности владения или распоряжения грузом указывает право страны грузоотправителя или грузополучателя, lex

${ }^{3}$ Ануфриева Л.П. Международное частное право: В 3-х т. Том 2. Особенная часть. М.: БЕК, 2002. С. 264.

${ }^{4}$ Садиков О.Н. Правовое регулирование международных перевозок. М., юрид. литература, 1981. С. 58 loci delicti commissi-на право государства транзита, lex venditores-национальность страны перевозчика, являющегося главным лицом в договоре перевозки. Применяя общие коллизионные нормы, в отношении перевозки могут иметь свое толкование, так закон места заключения договора понимается специфически - как право страны, где был начат первый участок перевозки 5 .

Если национальное законодательство государства не содержит специальных коллизионных привязок для регулирования международной перевозки определенного вида, то применяются общие коллизионные начала: закона перевозчика, закона суда, закона флага ${ }^{6}$.

Чрезвычайно распространенной является трансформация общих коллизионных начал (закон места нахождения вещи, места совершения договора) в специальные (закон дороги отправления, следования, транзита, назначения).

В соответствии со ст. 1211 ГК, при отсутствии соглашения сторон о выборе права применяется закон наиболее тесной связи (Proper Law), который понимается как закон места жительства или основного места деятельности той стороны отношения, которая осуществляет исполнение, имеющее решающее значение для содержания договора7 Следуя общему правилу установленному ГК п.6 ст. $1211^{8}$, к договору трубопроводной транспортировки следует применять право страны перевозчика.

Одной из особенностей договора трубопроводной транспортировки является то, что понятие данного договора пока не закреплено на законодательном уровне, что усложняет выбор применимого права на основании закона наиболее тесной связи. Но данный вопрос решается ГК, указывая, что к договору, содержащему элементы различных договоров, применяется, если иное не вытекает из закона, условий или существа договора либо совокупности обстоятельств дела, право страны, с которой этот договор, рассматриваемый в целом, наиболее тесно связан. Правило о смешенных договорах применимо также к тем внешнеэкономическим сделкам, которые основаны на нормах права иностранных государств и не всегда имеют аналоги в российском законодательстве, в связи с чем к ним необходимо применять вышеуказанное правило о непоименованных договорах.

\footnotetext{
${ }_{5}^{5}$ Гетьман-Павлова И.В. Международное частное право: Учебник. М.: Изд-во Эксмо, 2005. С. 253

${ }^{6}$ Бордунов Б.Д. Международное воздушное право. Москва: НОУ ВКШ «Авиабизнес», 2007. С.169

${ }^{7}$ Статья 1211ГК РФ. Право, подлежащее применению к договору при отсутствии соглашения сторон о выборе права

${ }^{8}$ Гражданский кодекс Российской Федерации (часть третья)» от 26.11.2001 N 146-Ф3 (ред. от 05.06.2012, с изм. от 02.10.2012) «Парламентская газета», N 224, 28.11.2001, «Российская газета», N 233, 28.11.2001, «Собрание законодательства РФ», 03.12.2001, N 49, ст. 4552.
} 
Согласно положениям ГК стороны могут заключить договор, в котором содержатся элементы различных договоров, предусмотренных законом или иными правовыми актами (смешанный договор). К отношениям сторон по смешанному договору применяются в соответствующих частях правила о договорах, элементы которых содержатся в смешанном договоре, если иное не вытекает из соглашения сторон или существа смешанного договора. Условия договора определяются по усмотрению сторон, кроме случаев, когда содержание соответствующего условия предписано законом или иными правовыми актами9. Если в договоре использованы принятые в международном обороте торговые термины, при отсутствии в договоре иных указаний считается, что сторонами согласовано применение к их отношениям обычаев делового оборота, обозначаемых соответствующими торговыми терминами. Согласно закону наиболее тесной связи правопорядок устанавливается путем толкования договора.

При осуществлении международных перевозок трубопроводным транспортом, возможно, применение принципа автономии воли сторон. Это связано с тем, что договор международной перевозки является одним из видов внешнеэкономических сделок ${ }^{10}$, которые в законодательстве большинства государств (в том числе, и в правовой системе Российской Федерации) могут регулироваться правом, выбранным сторонами. Автономия воли сторон стала одним из фундаментальных принципов международного частного права ${ }^{11}$.

Особенностью, усложняющей, выбор применимого права является стороны договора трубопроводной транспортировки. Коллизионные нормы играют важную роль в установлении применимого права к деятельностью многонациональных предприятий ${ }^{12}$ sub_10031.

Отношения, связанные с транспортировкой трубопроводным транспортом лицом, имеющим государственную принадлежность иного государства, чем другая сторона этих отношений, имеет международный характер. Как правило, подобные ситуация являются нормой современной реалии. Однако, возникают ситуации, когда принад-

\footnotetext{
${ }^{9}$ Гражданский кодекс Российской Федерации (часть третья)» от 26.11.2001 N 146-Ф3 (ред. от 05.06.2012, с изм. от 02.10.2012) «Парламентская газета», N 224, 28.11.2001, «Российская газета», N 233, 28.11.2001, «Собрание законодательства РФ», 03.12.2001, N 49, ст. 4552.Ст. 422.

${ }^{10} \mathrm{~B}$ тех государствах, где действует дуализм частного права, договор перевозки обычно относится к торговым сделкам в силу общих положений торгового права (ст.632-633 Торгового кодекса Франции, §1 Торгового уложения Германии).

11 Звеков В.П. Международное частное право.М.: Издательская группа НОРМА-ИНФРА М, 1999. С.286

${ }^{12}$ Tzuganatos $D$. Private International Law as a Means to Control the Multinational Enterprise//Vander built Journal of Transnational Law. 1986. V. 19. N 3. P. 477.
}

лежность одной из сторон подчас определить достаточно сложно, как например, с компаниями-оболочками, такие компании учреждены в иной юрисдикции, чем юрисдикции непосредственно основной деятельности или головного офиса. Ввиду того, что большинство судов применяют критерий инкорпорации для определения «национальности» юридического лица, вопрос компаний - оболочек становиться актуальный. Большинство компаний используют данный подход для выбора наиболее удобного режима инвестирования. Международный Суд ООН также отметил, что иногда применяется критерий места нахождения, или siege social ${ }^{13}$. Вопрос национальности одной из сторон договора является существенным, так как это может привести к тому, что стороны в итоге являются субъектами одной «национальности», в этом случае мы не может говорить о международно-правовом регулировании. В случае признания национальности компании-оболочки иной, нежели национальность второй стороны, то право какой из сторон следует применять. Если мы имеем дело с иностранными инвестициями, то «национальность» стороны определяет, под какой режим регулирования подпадает данная сторона и порядок рассмотрения споров.

Под компанией-оболочкой понимается корпорация, «которая не осуществляет деловую активность и обычно существует только номинально, как средство для осуществления деловых операций другой компании» ${ }^{14}$.

По данному вопросу в литературе имеются различные мнения, одни авторы предлагают применять критерий места нахождения в качестве основного для определения «национальности» юридического лица, но такой выбор должен рассматриваться в совокупности с остальными обстоятельствами, а не быть чисто механическим ${ }^{15}$.

В зависимости от того, коллизионные нормы какого государства будут применяться при определении национальности юридического лица, зависит, в частности, то, какой режим будет применяться к данному лицу: режим, установленный для деятельности иностранного юридического лица, или режим, применяемый к деятельности отечественных ${ }^{16}$. Согласно личному закону устанавливается

\footnotetext{
${ }^{13}$ Джеффри Салливан и Алекс Хиендл. Компании - оболочки и право иностранных инвестиций. Правовые аспекты инвестиционных договоров: сборник статей/М. Норма. 2012 С.148-171

${ }^{14}$ Цит. По Джеффри Салливан и Алекс Хиендл. Компании- оболочки и право иностранных инвестиций. Правовые аспекты инвестиционных договоров: сборник статей/М. Норма. 2012 C.148-171. Garner B.A. (ed.) Black's Law Dictionary. $8^{\text {th }}$ ed. West Publishing Co, 2004.

${ }^{15}$ Broches $A$. Bilateral Investment Protection Treaties and Arbitration of Investment Disputes// The Art of Arbitration, Liber Amicorum Pieter Sanders/ eds. By J.Shultz, A. van den Berg. 1982. P.63.

${ }^{16}$ Доронина Н.Г., Семилютина Н.Г. Международное частное право и инвестиции: науч.-практ. исслед. - М.:» Юридическая фирма «Контракт»; «Волтерс Клувер», 2011 г. - 163 с.
} 


\section{Право и политика $3(159) \cdot 2013$}

правоспобность юридического лица, правоспособность органов управления юридического лица, решаются вопросы представительства, кто несет ответственность по обязательствам компании.

Законодательство различных государств по-разному определяет, какое лицо является принадлежащим данному государству. Не существует универсального механизма определения национальности иностранного юридического лиц $\mathrm{a}^{17}$. Но тем не менее в результате длительной международной практики выработаны общие критерии квалификации объема правосубъектности отечественного или иностранного правопорядка. Таковыми считаются теория инкорпорации, теория оседлости, теория центра эксплуатации, теория контроля. Теория инкорпорации использует критерий учреждения или регистрации (инкорпорации) головных органов (административного центра, центра управления) юридического лица. Критерий инкорпорации (учреждения) сводится к тому, что компания принадлежит правопорядку страны, в которой она учреждена в соответствии с ее законодательством ${ }^{18}$. Теория оседлости иногда называется теорией «эффективного местопребывания», личным статутом юридического лица выступает закон того государства, в котором находится центр управления (совет директоров, управление, другие исполнительные органы). Согласно доктрине в данном случае не важно, где проходит деловая активность такого юридического лица. В числе стран, определенно занимавших такую правовую позицию, - Бельгия, Испания, Люксембург, Франция, ФРГ, большинство других стран Европейского союза. Теория центра эксплуатации. Здесь определяющим является то, что юридическое лицо в качестве личного закона имеет стимул того государства, где оно проводит хозяйственную деятельность. Данный критерий характерен для развивающихся стран. Теория контроля. Данный критерий имеет наибольшее применение в сфере правительственного регулирования иностранных инвестиций. Критерий контроля используется для идентификации действительной принадлежности юридического лица и лица, фактически его контролирующего. Единый исчерпывающий перечень признаков контроля отсутствует. По мере расширения международных частных отношений все более усложняется вопрос об установлении национальности юридического лица. Традиционные способы определения национальности юридического лица недостаточно эффективны в отношении международной частной транспортировки. Наиболее удачной представляется теория контроля. Для последней вообще характерен индивидуальный подход к каждому случаю.

${ }_{17}$ Фархутдинов И.З. Международное инвестиционное право и процесс: учебник. - «Проспект», 2010 г

${ }^{18}$ Международное частное право / под ред. Г.К. Дмитриевой. М.: Проспект, 2010. С. 124.
По мнению Н.Г. Дорониной, «категория национальности применительно к юридическим лицам чаще используется для разграничения собственных (национальных) и чужих (иностранных) юридических лиц и в целях определения правового режима деятельности последних в границах национально-правовой системы. При этом к иностранным («чужим» в данной правовой системе) могут относиться и часто относятся местные (собственные или национальные) юридические лица, контролируемые компаниями другого государства ${ }^{19} »$.

Анализируя вопрос определения государственной принадлежности юридического лица по общим критериям международного частного права, Н.Н. Вознесенская обоснованно указывает на недостаточность формальных признаков для международных частных правоотношений. Решение проблемы, по ее мнению, заключается в признании «за предприятием, двух правовых статусов: первый - общепринятый, определяемый личным законом (в России - законом места учреждения), и второй - обязательственный статус, определяющий непосредственно деятельность ${ }^{20}$.

По законодательству РФ личным законом организаций признается право того государства, где они учреждены, и к их деятельности на территории России применяются правила, которые регулируют деятельность юридических лиц. (ст. 1203 ГК РФ).

Принимая во внимание, что одной из последних тенденций международного частного права является гибкость подходов, поэтому следует этот вопрос рассматривать в совокупности и забегая вперед, учитывая последствиям, к которым может привести выбранное право.

Кроме международных частных транснациональных компаний, одной из сторон трубопроводной транспортировки могут быть государство или международная организация, которые занимают особые положения в международных частных отношениях. Эти публично-правовые образования, в силу особенностей их юридической природы и сущности, не являются типичными субъектами международного частного права. Вместе с тем, они также выступают в качестве в качестве стороны в частно-правовых отношениях, осложненных иностранным элементом.

Отношения в области трансграничной трубопроводной транспортировки осложняется непосредственным участием государства в таких частно-правовых отношениях, и затрагивает интересы нескольких государств. Государство от собственного имени или через государственную компанию принимает непосредственное участие в проекте.

\footnotetext{
${ }_{19}$ Доронина Н.Г. Комментарий к Закону об иностранных инвестициях. С. 72.

${ }^{20}$ Вознесенская Н.Н. Иностранные инвестиции: Россия и мировой
} опыт. С. 71-72. 
По мнению С.3. Жизнина ${ }^{21}$, роль и интересы государства в ходе строительства, эксплуатации трансграничного трубопровода определяются той функцией, которую это государство выполняет в проекте в целом, и местом этого государства в трубопроводной цепочке ${ }^{22}$. В зависимости от того является государство экспортером сырья, транзитной страной или импортером сырья, его интересы и цели участия в проекте, будут различны. Однако, несмотря на различие конкретных целей, заинтересованность участвующих государств, в строительстве трансграничного трубопровода и поддержка со стороны каждого из них являются необходимыми условиями осуществления проекта.

Государства, участвующие в строительстве трансграничного трубопровода, путем заключения рамочного межправительственного соглашения решают ряд задач общего характера, направленных как на обеспечение более эффективного осуществления проекта, так и на защиту своих интересов, например, Соглашение о реализации проекта «Южный поток» (South Stream) от 23 июня 2007 г., заключенное между итальянской «Эни» и ОАО «Газпром», Соглашение «Об основных принципах разработки ТЭО нефтепровода Россия-Китай» (ВСТО), подписанное правительствами России и КНР 17 июля 2001 г.; Соглашение о Каспийском трубопроводном консорциуме (КТК), подписанное в июне 1992 г., между правительствами РФ, Казахстана и Султаната Оман. Как указывает В. Загашвили ${ }^{23}$, для России своевременность участия в этих проектах означает возможность существенно активизировать внешнеэкономическую деятельность нефтегазовой промышленности и повысить эффективность ее функционирования, оздоровить ситуацию в отраслях ТЭК и в экономике в целом. Это тем более важно в связи с принятием Третьего Энергетического пакета Европейского союза и тенденциям централизованного развития европейской энергетической сети в обход России. По мере развития национального законодательства развивающихся стран появилась тенденция к подчинению ему условий недропользования, т.к. каждое государство стремиться управлять своими ресурсами. Однако, параллельно со становлением правового регулирования пользования недрами развивались: концепция lex contractus (Proper Law of the Contract), выразившееся в идее о самодостаточности договора пользования недрами в том смысле, что последние не подчиняются законам и иным нормативно-правовым актам государства и вторая это концепция признания договора пользования недрами с

\footnotetext{
${ }^{21}$ Жизнин 3. Основы энергетической дипломатии. - М. -2003. - т.1.

22 Жизнин C.3. Международный транзит в мировой энергетике. // Трубопроводный транспорт нефти. 2002.- № 7. - С. 40-42

23 Загашвили В. Интеграция России в мировое хозяйство: структурные проблемы // МЭиМО 1999г. №7.С.22-29.
}

иностранным элементом международным договором и распространения на него принципа pacta sunt servant ${ }^{24}$.

К определенным видам перевозок применяются свои формулы прикрепления. Особенности коллизионного регулирования транспортировки заключается в совмещении действия в каждом договоре нескольких коллизионных начал.

В отношении трубопроводной транспортировки также сформировались специальные коллизионные привязки - закон прохождения трубопровода ${ }^{25}$, право страны оператора трубопровода.

Важным является вопрос о возможности квалифицировать магистральные трубопроводы в качестве недвижимых вещей в смысле ст. 130 ГК РФ, что характерно для транспортных отношений вообще - рассматривать средство транспортировки как недвижимость в силу достаточно высокой стоимости.

Законодательство и правоприменительная практика признают трубопроводы в качестве объекта недвижимости. По мнению И.В. Гудкова их относят не к такой категории недвижимости, как «здания, сооружения», а в силу их комплексного состава квалифицируют как предприятия - имущественные комплексы, являющиеся недвижимостью в соответствии со статьей 132 ГК РФ. Так, именно в качестве предприятий - имущественных комплексов рассматриваются магистральные газопроводы в Указе Президента Российской Федерации от 5 мая 1999г. № $544^{26}$. Помимо указанных характеристик, а также неразрывной связи с землей, объекты трубопроводного транспорта можно рассматривать как недвижимость в силу достаточно высокой стоимости, по аналогии с иными видами транспорта ${ }^{27}$.

Принимая во внимание такую особенность объектов трубопроводного транспорта, представляется возможным применять коллизионные привязки, применяемые к объектам недвижимости, в частности ГК РФ указывает, что к объектам недвижимости следует применять закон места нахождения такой недвижимости. Данное правило

\footnotetext{
${ }^{24}$ Налетов Кирилл Игоревич. Лицензионные и договорно-правовые формы пользования недрами в РФ и за рубежом : диссертация... канд. юрид. наук : 12.00.06 Москва, 2006

${ }^{25}$ Дмитриева Г.К. Международное частное право: Учебник. Изд-во проспект, 2010. С.395

${ }^{26}$ Указ Президента Российской Федерации от 5 мая 1999г № 544 «Об обеспечении надежного функционирования единой системы газоснабжения при осуществлении ОАО «Газпром» мер по совершенствованию своей структуры». «Собрание законодательства РФ», 10.05.1999 № 19 Ст. 2319; «Российская газета» №91, 13.05.1999.

${ }^{27}$ Гудков И.В. Транспортировка газа в России: текущее состояние и перспективы нормативно-правового регулирования. Нефть, Газ и Право. №3 2009г. С.37
} 


\section{Право и политика $3(159) \cdot 2013$}

следует из содержания ст. 1213 ГК РФ, при отсутствии соглашения сторон о праве, подлежащем применению к договору в отношении недвижимого имущества, применяется право страны, с которой договор наиболее тесно связан. Правом страны, с которой такой договор наиболее тесно связан, считается, если иное не вытекает из закона, условий или существа договора либо совокупности обстоятельств дела, право страны, где находится недвижимое имущество. Но в отношении объектов трубопроводного права, подобный принцип является нецелесообразным, так как может привести к злоупотреблению транзитными странами. В литератуpe, указывается, что коллизионная привязка к закону местонахождения вещи не применяется, когда речь идет не о вещах как отдельных объектах вещного права, а о правах на имущественный комплекс, в состав которого входят вещные и обязательственные права, иногда авторские права, право на товарный знак, на фирменное наименование, товарный знак, знак обслуживания ${ }^{28}$. Отсылая к правопорядку страны, где находится движимое или недвижимое имущество, коллизионная норма не отвечает на вопрос, к какой категории будет отнесено имущество, являющееся предметом спора в стране, а это может иметь определенное значение для результата рассмотрения спора, так как понятия, которыми оперирует закон в одной стране, могут не соответствовать адекватным понятиям в другой стране.

Судьба имущества иностранного юридического лица определяется не по закону местонахождения указанного имущества, а по закону той страны, к которой принадлежит юридическое лицо. Российская доктрина исходит из того, что «имущественный комплекс подчиняется единому правовому режиму: судьба всех его частей должна быть едина. В связи с этим возможно предположить применение нормы ст. 1207 ГК, которая указывает, что к праву собственности и иным вещным правам на воздушные и морские суда, суда внутреннего плавания, космические объекты, подлежащие государственной регистрации, их осуществлению и защите применяется право страны, где эти суда и объекты зарегистрированы. Представляется возможным применять указанную коллизионную норму и в отношении объектов трубопроводного транспорта.

Договор на оказание услуг по транспортировке по трубопроводам содержат, как привило, одностороннюю коллизионную привязку, указывая непосредственно применимое правило. Например, за неисполнение или ненадлежащее исполнение обязательств по договору транспортировке стороны несут

\footnotetext{
${ }^{28}$ Международное частное право / под ред. О.Н. Садикова. М., 1984. С. 124; Луни Л.А. Международное частное право. Особенная часть. М., 1963. С. 84.
}

ответственность в соответствии с законодательством Российской Федерации ${ }^{29}$.

Общая особенность коллизионных норм в сфере международного транспорта заключается в подчинении основного института - договора перевозки действию нескольких коллизионных привязок (множественность или расщепленность привязок). Это обусловлено тем обстоятельством, что транспортировка фактически происходит по территории нескольких государств, в каждой из которой подлежим выполнению различные транспортные операции: отправление груза, транспортировка, выдача. Подчинение этих разных «транспортных этапов» одному правопорядку не учитывало бы особенности транспортного законодательства отдельных государств и создавало неудобства при выполнении перевозочных операций.

Современная особенность развития коллизионных привязок - отказ от «жестких» коллизионных норм, основанных на одном критерии выбора права. Для выбора права по одному вопросу используется система взаимосвязанных коллизионных норм. Главный способ выбора права - это применение гибких правил, позволяющих учитывать все конкретные обстоятельства дела. Правоотношение разбирается на статуты, и каждый статут имеет самостоятельное коллизионное регулирование. К каждому отдельному статуту применяется самостоятельное право - право того государства, с которым данная часть правоотношения наиболее тесно связана. Очень часто основной вопрос привязан к праву одного государства, а специальные вопросы этого же отношения - к праву другого государства. Подобная множественность коллизионных привязок проявляется в кумуляции коллизионных привязок, расщеплении коллизионной нормы.

Современная тенденция - единое коллизионное регулирование комплексных отношений, применение к ним общей коллизионной привязки. (п.5ст.1211 ГК РФ) ${ }^{30}$.

В последнее время, как указывает В.П. Звеков, процесс преодоления коллизионной проблемы становиться более гибким, сами же коллизионные нормы - и в этом одна из важнейших особенностей современного коллизионного права - перестают быть нейтральными, «безразличными» по отношению к выбору с их помощью применимого права ${ }^{31}$.

Один из недостатков, свойственных коллизионному способу регулирования, - возможность столкновения самих коллизионных норм, исчезает, когда эти нормы унифицируются в международном соглашении. Этим определение права, применимого к отношениям с ино-

29 ТИПОВАЯ ФОРМА ДОГОВОРА об оказании услуг по транспортировке нефти на 2012 год . http://www.transneft.ru/files/201204/981mn5dy0RkqWe..pdf

\footnotetext{
30 Забелова Л.Б. Международное частное право 2010.

31 Звеков В.П. Коллизии законов в международном частном праве.
} М.: Волтерс - Клувер, 2007. С.376. 
странным элементом, на основании унифицированной коллизионной нормы, единообразной во всех участвующих в унификации государствах, существенно отличается от выбора применимого закона в силу коллизионной нормы внутреннего права. По существу унификация коллизионных норм - это особая разновидность коллизионного метода регулирования.

Однако, как показывает опыт, унификация коллизионных норм, широко используется там, где дело касается отношений с участием граждан (наследование, семейное право и др.), сравнительно мало осуществляется с целью устранить коллизии таких норм в сфере регулирования предпринимательской деятельности. Особая «насыщенность» иностранным элементом отношений в сфере международного торгового мореплавания вообще и отношений по международным перевозкам в особенности предопределили использование для устранения и разрешения коллизий, возникающих в этой области отношений, всех известных международному частному праву способов.

Следует учитывать порядок применения международных коллизионных норм. При отсылке к какому-либо внутреннему праву необходимо последовательно применять: 1) специальные нормативные акты, касающиеся международных перевозок; 2) нормы транспортного законодательства; 3) нормы общегражданского законодательства. Раздел VI части третьей ГК РФ содержит ряд коллизионных привязок, которые применяются к внешнеэкономическим сделкам, если отсутствуют специальные коллизионные нормы транспортного законодательства ${ }^{32}$.

Один из недостатков, свойственных коллизионному способу регулирования, - возможность столкновения самих коллизионных норм, исчезает, когда эти нормы унифицируются в международном соглашении. Этим определение права, применимого к отношениям с иностранным элементом, на основании унифицированной коллизионной нормы, единообразной во всех участвующих в унификации государствах, существенно отличается от выбора применимого закона в силу коллизионной нормы внутреннего права.

Коллизионные нормы, определяющие закон страны для некоторых видов имущества на основе критерия места регистрации этого имущества, наибольшим образом приближаются к тем коллизионным нормам, которые могли бы быть выделены для определения закона страны, подлежащего применению к трубопроводной транспортировке. Закон места регистрации трубопровода, подобно закону места регистрации судна, внес бы определенность в отношении защиты прав на это имущество, основным свойством которого

${ }^{32}$ Канашевский В.А. Внешнеэкономические сделки. Правовое регулирование. М: Международные отношения. 2005. С.236 является нахождение в постоянном движении (пересекая границы различных стран и попадая из одной юрисдикции в другую).

Коллизионно-правовое регулирование отношений трубопроводной транспортировки характеризуется, во-первых, применением общепризнанных коллизионных норм совместно со специальными транспортными коллизионными принципами; вовторых, объективная потребность создания новых или приспособления традиционных коллизионных принципов и норм путем их толкования для регулирования вновь возникающих отношений.

От воли законодателя зависит, будет ли отнесено то или иное имущество к категории движимого или недвижимого, будет ли то или иное лицо рассматриваться как иностранный или отечественный инвестор, а соответственно, и какой режим будет применен к этому лицу или имуществу . Поскольку международная трубопроводная транспортировка имеет дело с перемещаемым из одной юрисдикции в другую имуществом, то наиболее наглядно роль коллизионных норм в отношении вещного права на имущество инвестора можно показать на примере имущества, чьим свойством является пересечение границ, различных юрисдикции. Для такого имущества существует свой критерий определения подлежащего применению закона. Это закон страны регистрации этого имущества.

Появление новых видов транспортировки, а также их комбинирование породило целый ряд новых коллизионных принципов, а также адаптации уже существующих принципов к новым отношениям.

Эффективность правового регулирования международных транспортных отношений обусловлена унификацией и гармонизацией материальных правовых норм и принципов, что обеспечивает единообразную практику их применения ${ }^{33}$. Наличие коллизионных норм, унифицированных в международной конвенции, упрощало бы решение коллизионных вопросов, поскольку субъекты отношений по трубопроводной транспортировки государств, участву-

\footnotetext{
${ }^{33}$ Например, Международное частное морское право: Международная конвенция об унификации некоторых правил, касающихся коносамента 1924г. (Гаагские правила); Протокол изменений к Международной конвенции об унификации некоторых правил, касающихся коносамента 1968г. (Правила Висби); Конвенция ООН по морской перевозке грузов 1978г. (Гамбургские Правила); Афинская конвенция о перевозке морем пассажиров и из багажа 1974г.; Протокол об изменении Афинской конвенции 1990г.; Йорк-Антверпенские правила в редакциях 1950г., 1974г., 1974г. С изменениями 1990г.; Международная Конвенция о спасании 1989г; Международная Конвенция для объединения некоторых правил относительно столкновения судов 1910г.; Международная конвенция об унификации некоторых правил об ограничении ответственности собственных морских судов 1924г., Конвенция об ограничении ответственности судовладельцев 1957г;; Конвенция об ограничении ответственности по морским требованиям 1976г.
} 


\section{Право и политика 3 (159) • 2013}

ющих в данной конвенции, применяли бы единообразные коллизионные нормы, то есть определяли бы применимое право на основании единых коллизионных принципов.

По словам О.Н. Садикова, наиболее широко используемым правовым средством, обеспечивающим применение к международным перевозкам внутреннего права, остаются коллизионные нормы ${ }^{34}$.

\section{Библиография:}

1. Broches A. Bilateral Investment Protection Treaties and Arbitration of Investment Disputes// The Art of Arbitration, Liber Amicorum Pieter Sanders/ eds. By J.Shultz, A. van den Berg. 1982. P.63. 2.

2. Chisholm Archibald. The first Kuwait concession Agreements/ London/ 1975 P. 168-170

3. Tzuganatos D. Private International Law as a Means to Control the Multinational Enterprise//Vander built Journal of Transnational Law. 1986. V. 19. N 3. P. 477.

4. Ануфриева Л.П. Международное частное право: В 3-х т. Том 2. Особенная часть. М.: БЕК, 2002. С. 264.

5. Бордунов Б.Д. Международное воздушное право. Москва: НОУ ВКШ «Авиабизнес», 2007. С.169

6. Вознесенская Н.Н. Иностранные инвестиции: Россия и мировой опыт. С. 71-72.

7. Гетьман-Павлова И.В. Международное частное право: Учебник. М.: Изд-во Эксмо, 2005. С. 253

8. Гражданский кодекс Российской Федерации (часть третья)» от 26.11.2001 N 146-Ф3

9. Гудков И.В. Транспортировка газа в России: текущее состояние и перспективы нормативно-правового регулирования. Нефть, Газ и Право. №3 2009г. С.37

10. Джеффри Салливан и Алекс Хиендл. Компании- оболочки и право иностранных инвестиций. Правовые аспекты инвестиционных договоров: сборник статей/М. Норма. 2012 С.148-171

11. Дмитриева Г.К. Международное частное право: Учебник. Изд-во проспект, 2010. С.395

12. Доронина Н.Г., Семилютина Н.Г. Международное частное право и инвестиции: науч.-практ. исслед. - М.:»Юридическая фирма «Контракт»; «Волтерс Клувер», 2011 г. - 163 с.

13. Доронина Н.Г. Комментарий к Закону об иностранных инвестициях. С. 72.

14. Жизнин 3. Основы энергетической дипломатии. - М. $-2003 .-$ т.1.

15. Жизнин С.3. Международный транзит в мировой энергетике. // Трубопроводный транспорт нефти. 2002.- № 7. - C. 40-42

${ }^{34}$ Садиков О.Н. Правовое регулирование международных перевозок. М., юрид. литература, 1981. С.57
16. Забелова Л.Б. .Международное частное право 2010.

17. Загашвили В. Интеграция России в мировое хозяйство: структурные проблемы // МЭиМО 1999г. №7.C.22-29.

18. Звеков В.П. Коллизии законов в международном частном праве. М.: Волтерс - Клувер, 2007. С.376.

19. Звеков В.П. Международное частное право.М.: Издательская группа НОРМА-ИНФРА М, 1999. С.286

20. Канашевский В.А. Внешнеэкономические сделки. Правовое регулирование. М: Международные отношения. 2005. С.236

21. Кокин А.С, Международная морская перевозка груза. М.: Волтерс Клувер, 2007. С.194

22. Лунц Л.А. Международное частное право. Особенная часть. М., 1963. С. 84.

23. Налетов Кирилл Игоревич. Лицензионные и договорно-правовые формы пользования недрами в РФ и за рубежом : диссертация... канд. юрид. наук : 12.00 .06 Москва, 2006

24. Садиков О.Н. Международное частное право, 1984;

25. Садиков О.Н. Правовое регулирование международных перевозок. М., юрид. литература,1981. С. 58

26. Фархутдинов И.З. Международное инвестиционное право и процесс: учебник. - «Проспект», 2010 г

27. Филимонова М.В. К вопросу о регулировании трансграничной трубопроводной транспортировки. Право: теория и практика. № 13 2006. С. 5

\section{References (transliteration):}

1. Broches A. Bilateral Investment Protection Treaties and Arbitration of Investment Disputes// The Art of Arbitration, Liber Amicorum Pieter Sanders/ eds. By J.Shultz, A. van den Berg. 1982. P.63. 2.

2. Chisholm Archibald. The first Kuwait concession Agreements/ London/ 1975 P. 168-170

3. Tzuganatos D. Private International Law as a Means to Control the Multinational Enterprise//Vander built Journal of Transnational Law. 1986. V. 19. N 3. P. 477.

4. Anufrieva L.P. Mezhdunarodnoe chastnoe pravo: V 3-kh t. Tom 2. Osobennaya chast'. M.: BEK, 2002. S. 264.

5. Bordunov B.D. Mezhdunarodnoe vozdushnoe pravo. Moskva: NOU VKSh «Aviabiznes», 2007. S.169

6. Voznesenskaya N.N. Inostrannye investitsii: Rossiya i mirovoy opyt. S. 71-72.

7. Get'man-Pavlova I.V. Mezhdunarodnoe chastnoe pravo: Uchebnik. M.: Izd-vo Eksmo, 2005. S. 253

8. Grazhdanskiy kodeks Rossiyskoy Federatsii (chast' tret'ya)» ot 26.11.2001 N 146-FZ

9. Gudkov I.V. Transportirovka gaza v Rossii: tekushchee sostoyanie i perspektivy normativno-pravovogo regulirovaniya. Neft', Gaz i Pravo. №3 2009g. S.37 
10. Dzheffri Sallivan i Aleks Khiendl. Kompanii- obolochki i pravo inostrannykh investitsiy. Pravovye aspekty investitsionnykh dogovorov: sbornik statey/M. Norma. 2012 S.148-171

11. Dmitrieva G.K. Mezhdunarodnoe chastnoe pravo: Uchebnik. Izd-vo prospekt, 2010. S.395

12. Doronina N.G., Semilyutina N.G. Mezhdunarodnoe chastnoe pravo i investitsii: nauch.-prakt. issled.-M.:»Yuridicheskaya firma «Kontrakt»; «Volters Kluver», 2011 g. - 163 s.

13. Doronina N.G. Kommentariy k Zakonu ob inostrannykh investitsiyakh. S. 72.

14. Zhiznin Z. Osnovy energeticheskoy diplomatii. - M. 2003. - t.1.

15. Zhiznin S.Z. Mezhdunarodnyy tranzit v mirovoy energetike. // Truboprovodnyy transport nefti. 2002.- № 7. - S. 40-42

16. Zabelova L.B. .Mezhdunarodnoe chastnoe pravo 2010.

17. Zagashvili V. Integratsiya Rossii v mirovoe khozyaystvo: strukturnye problemy // MEiMO 1999g. №7.S.22-29.

18. Zvekov V.P. Kollizii zakonov v mezhdunarodnom chastnom prave. M.: Volters - Kluver, 2007. S.376.
19. Zvekov V.P. Mezhdunarodnoe chastnoe pravo.M.: Izdatel'skaya gruppa NORMA-INFRA M, 1999. S.286

20. Kanashevskiy V.A. Vneshneekonomicheskie sdelki. Pravovoe regulirovanie. M: Mezhdunarodnye otnosheniya. 2005. S.236

21. Kokin A.S, Mezhdunarodnaya morskaya perevozka gruza. M.: Volters Kluver, 2007. S.194

22. Lunts L.A. Mezhdunarodnoe chastnoe pravo. Osobennaya chast'. M., 1963. S. 84.

23. Naletov Kirill Igorevich. Litsenzionnye i dogovorno-pravovye formy pol'zovaniya nedrami v RF i za rubezhom : dissertatsiya... kand. yurid. nauk : 12.00.06 Moskva, 2006

24. Sadikov O.N. Mezhdunarodnoe chastnoe pravo, 1984;

25. Sadikov O.N. Pravovoe regulirovanie mezhdunarodnykh perevozok. M., yurid. literatura,1981. S. 58

26. Farkhutdinov I.Z. Mezhdunarodnoe investitsionnoe pravo i protsess: uchebnik. $-\ll$ Prospekt», $2010 \mathrm{~g}$

27. Filimonova M.V. K voprosu o regulirovanii transgranichnoy truboprovodnoy transportirovki. Pravo: teoriya i praktika. № 13 2006. S. 5 